УДК 347.4

DOI https://doi.org/10.51989/NUL.2021.6.5

\title{
КОМПЕНСАЦІЯ ЗА ПОРУШЕННЯ АВТОРСЬКОГО І СУМІЖНИХ ПРАВ ЯК ОСОБЛИВА ФОРМА ЦИВІЛЬНО-ПРАВОВОЇ ВІДПОВІДАЛЬНОСТІ
}

\author{
Черкашин Сергій Валерійович, \\ аспірант кафедри цивільного права № 1 \\ Національного юридичного університету імені Ярослава Мудрого
}

Значення авторських і суміжних прав суттєво зросло за останні декілька років, водночас змінювалися підходи до їх захисту. Регламентація способів захисту авторських $і$ суміжних прав на території ЄС суттєво відрізнялась від вітчизняних норм. До 2018 року способи захисту авторських і суміжних прав та їх особливості були майже такими, як і у 1993 році, коли було створено Закон України «Про авторське право і суміжні права». 3 прийняттям Закону України «Про ефективне управління майновими правами правовласників у сфері авторського права і (або) суміжних прав» у Законі України «Про авторське право та суміжні права» з'явились норми, які повторюють положення Директиви 2004/48/ЄС.

у межах статті увага буде приділена новій редакції компенсації за порушення авторських і суміжних прав. Незважаючи на те, що вітчизняний законодавець імплементував загальноєвропейський стандарт, не було враховано досвід застосування саме такого варіанта компенсації за порушення авторських і суміжних прав у сусідніх країнах. Через це чинне формулювання компенсації за порушення авторських і суміжних прав поєднує штрафний та компенсаційний характер. Окрім того, вбачається дисгармонія основних елементів компенсації за порушення авторських і суміжних прав та відшкодування збитків. Так, компенсація за порушення авторських і суміжних прав широко оперує механізмом гіпотетичного вирахування ліцензійної винагороди правоволодільця, якщо б його майнові права не були порушені. Водночас вітчизняне цивільне законодавство помірковано ставиться до можливості стягнути упущену вигоду, вимагаючи максимально повного та достовірного підтвердження реальності такої можливості. Саме тому попередня редакція ст. 52 зУ «Про авторське право та суміжні права» із суто штрафною компенсацією краще вписувалась у систему цивільного законодавства України.

Ключові слова: захист авторських прав, компенсація за порушення авторських і суміжних прав, гіпотетичне роялті, форма цивільно-правової відповідальності.

\section{Cherkashyn Serhii. Compensation for copyright and related rights violations as a special form of civil liability}

The importance of copyright and related rights has grown during the past few years. At the same time legal norms dedicated to the protection of intellectual property rights have changed too. Methods of protection of copyright and related rights in the EU differed significantly from domestic norms. Until 2018, the methods of protection of copyright and related rights were almost the same as in 1993, when the Law of Ukraine «On Copyright and Related Rights» was created. With the adoption of the Law of Ukraine "On effective management of property rights of copyright holders in the field of copyright and (or) related rights" in the Law of Ukraine "On Copyright and Related Rights" appeared rules that repeat the provisions of Directive 2004/48/EU.

In this article, attention will be paid to the new version of compensation for infringement of copyright and related rights. Despite the fact that the domestic legislator implemented the panEuropean standard, however, the experience of applying compensation for copyright and related rights violations was not taken into account. As a result, the current form of compensation for infringement of copyright and related rights combines penalties and compensatory nature. In addition, there is a disharmony of the main elements of compensation for copyright and related rights and damages. Thus, compensation for infringement of copyright and related rights widely operates the mechanism of hypothetical deduction of royalties of the owner's right if his property rights were not violated. At the same time, domestic civil law is moderate to the possibility of recovering lost profits, requiring the most complete and reliable confirmation of the reality of such a possibility. That is why the previous version of Art. 52 of the Law "On Copyright and Related Rights" with purely punitive compensation better fit into the system of civil law of Ukraine.

Key words: copyright protection, compensation for copyright and related rights infringement, hypothetical royalties, form of civil liability. 
Вступ. Регламентація ефективних форм цивільно-правової відповідальності за порушення авторських і суміжних прав $\epsilon$ актуальним питанням. Україна рухається в бік європейської інтеграції, тому імплементує стандарти ЄС щодо захисту авторських і суміжних прав.

Постановка завдання. Мета статті полягає у дослідженні стягнення компенсації за порушення авторського і суміжних прав як форми цивільно-правової відповідальності.

Результати дослідження. В сучасних умовах порушення прав інтелектуальної власності або не зменшують майнову сферу потерпілого, або зменшують так, що встановити прямий зв'язок між порушенням та шкідливими наслідками, які необхідні для відшкодування реальних збитків, дуже складно. Якщо проаналізувати судову практику з 2014 року, то можна побачити, що у справах, пов'язаних із порушенням авторського і суміжних прав, прослідковується тенденція відмови від позовів про відшкодування реальних збитків на користь стягнення компенсації фіксованого розміру.

Причиною такого підходу $є$ спрощення у доказуванні. Підставою для застосування компенсації за порушення авторського й суміжних прав $€$ доведений факт зменшення майнового блага потерпілого, але без підтвердження конкретного розміру [11, с. 94-96]. Наявність вини порушника авторських прав $€$ факультативною умовою, за якої розмір відповідальності порушника збільшується. Збільшення розміру відповідальності за наявності вини $\epsilon$ винятковим для вітчизняного цивільного законодавства, оскільки зазвичай ЦК України передбачає зменшення розміру відповідальності за відсутності вини (наприклад, ч. 3 ст. 23, п. 5 ч. 2 ст. 432 ЦК України).

На думку А. Штефан, що заслуговує на увагу, ця форма цивільно-правової відповідальності мала 6 існувати лише для вузького кола цивільних відносин, коли розмір спричиненої шкоди авторським і суміжним правам визначити неможливо [12, с. 41-51]. Слід констатувати, що законодавець у п. «Г» ч. 2 ст. 52 ЗУ «Про авторське право та суміжні права» не зробив уточнення винятковості такої форми відповідальності, тобто мало би бути таке застереження: «за неможливості встановлення розміру реальних збитків». Через це компенсація за порушення авторського і суміжних прав фактично стала головною формою цивільно-правової відповідальності за порушення авторських і суміжних прав. Верховний Суд України не оцінював превалювання саме компенсації над відшкодуванням збитків, надавши роз'яснення щодо визначення розміру такої компенсації у Постанові Пленуму від 4 червня 2010 року № 5 [9]. У пункті 42 Суд надав орієнтири для визначення розміру компенсації, які фактично зводяться до принципів розумності та співрозмірності. Зазвичай суди не допускають явно надмірних сум компенсацій, оскільки враховують суттєвість або несуттєвість порушення [10]. Так би мовити, "maleficia propositis distinguuntur", хоча ЗУ «Про авторське право та суміжні права» не дає змоги відмовляти у задоволенні позову про стягнення компенсації через малозначність порушення авторського і суміжних прав [5-7].

3 огляду на популярність компенсації за порушення авторських і суміжних прав як форми цивільно-правової відповідальності необхідно встановити ї̈ характер. Під час дослідження цієї форми цивільно-правової відповідальності необхідно порівняти редакцію ЗУ «Про авторське право та суміжні права» до і після 2018 року, а також дослідити зарубіжний досвід захисту прав інтелектуальної власності.

22 липня 2018 року набув чинності Зу «Про ефективне управління майновими правами правовласників у сфері авторського права і (або) суміжних прав», який запровадив зміни до ЗУ «Про авторське право і суміжні права» та трансформував механізм компенсації за порушення авторських і суміжних прав. Якщо до 2018 року компенсація являла собою штраф від 10 до 50000 мінімальних розмірів заробітної плати, тобто була суто штрафною санкцією, яка за законодавчою технікою іï регламентації близька до відповідальності за адміністративні правопорушення, то тепер компенсація визначається законодавцем як паушальна сума - подвоєна, а в разі умисного порушення - як потроєна сума винагороди або комісійних платежів, 
які були 6 сплачені порушником, якщо 6 він звернувся із заявою до правовласника про надання дозволу на використання оспорюваного авторського права або суміжних прав [8].

Описані зміни до ЗУ «Про авторське право та суміжні права» $\epsilon$ результатом імплементації Директиви 2004/48/ЄC [2]. Компенсація складається 3 можливо вірогідної винагороди правоволодільця (ліцензіара) від укладення ліцензійного договору з порушником. Таку конструкцію у практиці США та Великобританії часто іменують гіпотетичним роялті ("hypothetical royalty"). Ï̈̈ сутність вкрай проста: кожен примірник твору, який був незаконно поширений, вважається непроданим примірником правоволодільця [1]. Такий простий механізм підрахунку не $\epsilon$ офіційно регламентованим, хоча активно обговорюється серед практикуючих юристів галузі інтелектуальної власності.

Найближчою правовою конструкцією гіпотетичного роялті у вітчизняному цивільному законодавстві $\epsilon$ упущена вигода як складова частина збитків, передбачена ст. 22 ЦК України. Однаковим $€$ основний механізм: потерпілий має право стягнути з порушника дохід, на який він розраховував за умов відсутності правопорушення. Проте $\epsilon$ велика розбіжність між гіпотетичним роялті та упущеною вигодою. За чинним ЦК України, потерпілий має довести реалістичність упущеної вигоди, натомість у конструкції гіпотетичного роялті існує презумпція того, що правоволоділець зазнав конкретної втрати. Подібна презумпція прослідковується в компенсації за порушення авторських і суміжних прав у ст. 52 ЗУ «Про авторське право та суміжні права». Так, Закон не вимагає реальності ціни ліцензійного договору, їі відповідності ринковим показникам, реалістичності укладання тощо. 3 одного боку, можна говорити про спрощення процедури захисту порушених прав. 3 іншого боку, вбачається широкий простір для зловживання правом або безпідставного збагачення, коли правовласник не збирався монетизувати порушене авторське та (або) суміжне право; ціни на ліцензійний договір $€$ явно завищеними; правовласник через свої ділові якості не зміг би реалізувати ту кількість примірни- ків, яку зміг реалізувати порушник авторського або суміжного права; невідомий час формування вартості ліцензійного договору. Щодо останнього зауваження, то ЗУ «Про авторське право та суміжні права» не вимагає дотримання якогось часового проміжку для формування розміру комісійного платежу або винагороди, що дає змогу як використовувати ціни десятирічної давності, так і сформувати їх у день подання позову.

Встановлення об'єктивної винагороди власнику оспорюваного права інтелектуальної власності не має такого значення, як під час відшкодування збитків, оскільки компенсація передбачає подвоєння або потроєння розміру винагороди. Встановлення штрафного характеру компенсації видається сумнівним елементом, на який звертають увагу науковці [11, с. 41-51; 13 , с. 262-263; 14]. Не випадково, більшість держав-членів ЄС відмовилась від імплементації цього правила з Директиви 2004/48/ЄC [1]. Окрім того, перед введенням у вітчизняне законодавство положень Директиви слід було врахувати одинадцятирічний досвід у законодавстві Республіки Польща. Аналогічна норма була імплементована у ст. 79 Закону про авторське право і суміжні права Республіки Польща ще у 2007 році у зв'язку з необхідністю виконання Угоди про асоціацію з ЄС. Норма про стягнення компенсації, яка складається з трикратних платежів, які б отримав правоволоділець у разі надання ним згоди на використання об'єкта у 2015 році, була вилучена Конституційним Трибуналом Республіки Польщі. У рішенні Конституційного Трибуналу було зазначено, що така норма суперечать ст. 64 Конституції Республіки Польща, оскільки майнові авторські права вже перебувають під захистом конституційних положень ч. ч. 1, 2 ст. 64 Конституції Республіки Польща. Інтенсивність їхнього захисту у законі та Конституції має бути ідентичною або подібною до захисту права власності чи захисту інших майнових прав, яких стосується зазначена стаття. Трибунал справедливо наголосив на тому, що кратні суми $€$ непропорційними та ставлять у заздалегідь невигідне становище порушника, перетворюючись із компенсаційної конструкції у надкаральну [4]. На нашу думку, така позиція 
Конституційного Трибуналу $\epsilon$ справедливою, оскільки двократні або трикратні штрафні санкції виглядають надмірно жорсткими порівняно з іншими формами цивільно-правової відповідальності. Окрім того, форми цивільно-правової відповідальності сформульовані або як такі, що спрямовані на компенсацію, тому під час розрахунку їх розміру беруться максимально об'єктивні показники, або як штрафні форми цивільно-правової відповідальності, які стягнути простіше через спрощену систему доказування, адже в основу їх розрахунку покладається тверда сума.

У 2017 році положення про двократну суму платежів, які належали би правоволодільцеві у разі надання ним згоди на використання об'єкта у ст. 79 Закону про авторське право і суміжні права Республіки Польща, стало предметом розгляду Європейського Суду Справедливості (справа С-367/15) [3]. «У своєму рішення від 25 січня 2017 року у цій справі Суд дійшов висновку, що ст. 13 (1) (b) Директиви 2004/48/€С не перешкоджає закріпленню в національному законодавстві положень про те, що правоволоділець майнових авторських прав, чиї права були порушені, може вимагати від особи, яка порушила ці права, компенсувати заподіяні втрати сплатою суми, що відповідає подвійному розміру гіпотетичного роялті. На нашу думку, на особливу увагу заслуговують аргументи Суду у мотивувальній частині рішення.

1) Суд звернув увагу на те, що компенсація, обчислена на базі подвійної суми гіпотетичних роялті, не $€$ точно пропорційною втратам, яких фактично зазнав потерпілий, це $є$ притаманним будь-якій компенсації у вигляді паушальної суми, передбаченої ст. 13 (1) (b) Директиви 2004/48/ЄС (п. 26).

2) Така компенсація за своєю сутністю не $\epsilon$ каральними збитками, хоча Суд одночасно зазначив, що Директива 2004/48/ЄС не містить прямої заборони щодо запровадження таких збитків (п. п. 28, 29).

3) Суд наголосив на тому, що під час порушення права інтелектуальної власності проста сплата гіпотетичного роялті не здатна гарантувати компенсацію усіх витрат, яких фактично було завдано, на які $\epsilon$ посилання у п. 26 преамбули Директиви 2004/48/ЄС (п. 30)» [12, с. 262-264].

На нашу думку, аргументи Суду яскраво демонструють невідповідність ідей, закладених у Директиві 2004/48/ЄС, вітчизняному цивільному законодавству. По-перше, компенсація, яка $є$ альтернативою повного відшкодуванням збитків, не може передбачати повне відшкодування шкоди, незалежно від того, паушальна це сума чи ні. Компенсація застосовується за спрощеним алгоритмом, тому a priori не передбачає повної тотожності реальним збиткам. По-друге, якщо законодавець бажає встановити штрафну санкцію, то має використовувати тверду суму для ії̈ розрахунку, як це було у первинній редакції зу «Про авторське право та суміжні права» для того, щоб діяв принцип правової визначеності та оперативності. По-третє, якщо позивач має змогу визначити повний розмір завданих йому збитків, то компенсація як альтернатива відшкодуванню збитків не потрібна. Як було зазначено, немає жодної потреби у зрівнянні відшкодування збитків та компенсації, оскільки вони $\epsilon$ альтернативами між собою, які мають суттєві відмінності.

Висновки. Підсумовуючи викладене, слід констатувати, що чинний ЗУ «Про авторське право і суміжні права» містить особливу форму цивільно-правової відповідальності, яка суттєво відрізняється від інших форм цивільно-правової відповідальності. Слід зазначити, що запропонована законодавцем варіація компенсації за порушення авторського права і суміжних прав сформульована невдало. Очевидно, що імплементована норма була введена без урахування вже наявного досвіду. Великою теоретичною проблемою чинного механізму формулювання розміру компенсації $\epsilon$ поєднання компенсаційного та штрафного характеру. При цьому спосіб формулювання компенсаційної складової частини надає широкий простір для зловживань з боку потерпілого. На нашу думку, більш збалансованою $€$ штрафна санкція, яка має чіткі межі розміру. 


\section{ЛITEPATУPA:}

1. Nimmer D. Investigating the hypothetical "reasonable royalty" for copyright infringement. Boston University Review. 2019. Vol. 99:1. URL: https://www.bu.edu/bulawreview/files/2019/01/ NIMMER.pdf (дата звернення: 30.11.2021).

2. Directive 2004/48/EC of the European Parliament and of the Council of 29 April 2004 on the enforcement of intellectual property rights (OJ $L$ 157, 30.4.2004). URL: https:// eur-lex.europa.eu/legal-content/EN/TXT/?uri=CELEX\%3A32004L0048R\%2801\%29 (дата звернення: 30.11.2021).

3. Judgment of the Court of justice of the European Union of 27 January 2017 in Case C-367/15 Stowarszyszenie "Olawska Telewizja Kablowa" v Stowarszyszenie Filmowcow Polskich. URL: https://eur-lex.europa.eu/legal-content/EN/TXT/?uri=CELEX\%3A62015CA0367 (дата звернення: 30.11.2021).

4. Wyrok Trybunalu Konstytucyjnego Rzeczypospolitej Polskiej z dnia 23 czerwca 2015 sygn. Akt SK 32/14. URL: http://isap.sejm.gov.pl/isap.nsf/DocDetails.xsp?id=WDU20150000932 (дата звернення: 30.11.2021).

5. Постанова Вищого господарського суду України від 12 квітня 2016 року. Справа № 916/4567/14. URL: http://www.reyestr.court.gov.ua/Review/57169375 (дата звернення: 30.11.2021).

6. Постанова Вищого господарського суду України від 18 серпня 2015 року. Судова справа № 910/23835/14. URL: https://reyestr.court.gov.ua/Review/48820765 (дата звернення: 30.11.2021).

7. Про застосування судами норм законодавства у справах про захист авторського права і суміжних прав : Постанова Пленуму Верховного Суду України від 4 червня 2010 року № 5. URL: https://zakon.rada.gov.ua/laws/show/v0005700-10\#Text (дата звернення: 30.11.2021).

8. Про авторське право і суміжні права : Закон України від 23 грудня 1993 року № 3792-XII. Дата оновлення: 14 серпня 2021 року. URL: https://zakon.rada.gov.ua/laws/ show/3792-12\#n492 (дата звернення: 30.11.2021).

9. Про деякі питання практики застосування господарськими судами законодавства про захист прав на об'єкти інтелектуальної власності : Оглядовий лист Вищого господарського суду України від 28 лютого 2017 року № 01-06/52. URL: https://zakon.rada.gov.ua/laws/ show/v_521600-17\#Text (дата звернення: 30.11.2021).

10. Рішення Господарського суду Одеської області від 10 березня 2015 року. Справа № 916/4567/14. URL: https://reyestr.court.gov.ua/Review/43117519 (дата звернення: 30.11.2021).

11. Селіванов М. Шкода як необхідна підстава застосування компенсації при захисті авторського права та суміжних прав. Вісник Харківського національного університету імені В. Каразіна. 2017. Вип. 24. С. 94-96.

12. Штефан А. Цивільно-правові способи захисту авторського права і суміжних прав. Теорія і практика інтелектуальної власності. 2009. № 2. С. 41-51.

13. Якубовський I. Компенсація за порушення майнових прав інтелектуальної власності: проблеми теорії та практики. Право України. 2019. № 1. С. 262-264.

14. Яркіна Н. До проблеми застосування «оновленої» компенсації за порушення авторських і (або) суміжних прав (на основі аналізу судової практики). Теорія і практика правознавства. 2020. Вип. 2 (18). URL: http://nbuv.gov.ua/UJRN/tipp_2020_2_8 (дата звернення: 30.11.2021). 